APŽVALGINIS STRAIPSNIS

UDK 528.422

\title{
LIETUVOS ADMINISTRACINIS SKIRSTYMAS XIX ir XX a. RUSIJOS ŽEMĖLAPIUOSE
}

\author{
Algirdas Gliožaitis \\ Justiniškiu g. 115-68, LT-05245 Vilnius, Lietuva \\ Iteikta 200511 10, priimta 20060317
}

Tęsinys. Pradžia - „Geodezija ir kartografija“, XXXII t., Nr. 2.

\section{Caro Aleksandro I laikų žemèlapiai ir dokumentai}

Caras Aleksandras I valdè nuo $1801 \mathrm{~m}$. iki 1825 metų. Jis administracinio valdymo tikslams realizuoti $1801 \mathrm{~m}$. rugsèjo 9 d. Vilniuje issteigè braižyklą, kuriai buvo pavesta sudarinėti privačių, bažnytinių, valstybinių žemės valdų, miestų žemių planus ir žemėlapius (uždaryta 1917 m.) [12]. $1801 \mathrm{~m}$. rugsėjo 21 d. caro isaku Lietuvos gubernija padalyta i Lietuvos Vilniaus ir Lietuvos Gardino gubernijas. Lietuvos Gardino gubernija ikurta vietoje buvusios Slanimo „namiestničestvos“. Caras 1802 m. su didžiule palyda atvažiavo į Vilnių. Tilžèje 1807 m. liepos 7 d. pasirašyta Rusijos ir Prancūzijos sutartis, kuri, deja, neapsaugojo šių valstybių nuo karo. Jis prasidejo 1812 m. Po sutarties pasirašymo Napoleonas sudare Varšuvos Kunigaikštystę. Jai priklausė ir dalis Lietuvos - Užnemunė. Palangos valsčius 1819 m. atskirtas nuo Vilniaus gubernijos ir priskirtas prie Kuršo. Priskirdamas Palangą Kuršui, caras, kuris buvo laikomas liberaliu, stengèsi patenkinti vokiečių baronų, reikalavusių patogesnio susisiekimo su Prūsija, interesus.

Baltarusijos gubernija buvo padalyta i Baltarusijos Vitebsko ir Baltarusijos Mogiliovo gubernijas, Baltarusijos Vitebsko gubernija issikūrè vietoje buvusios Polocko „namiestničestvos“. Tarp Vilniaus ir Minsko guberniju 1806 m. detaliai nustatyta riba $[13,14]$ (10 pav.).

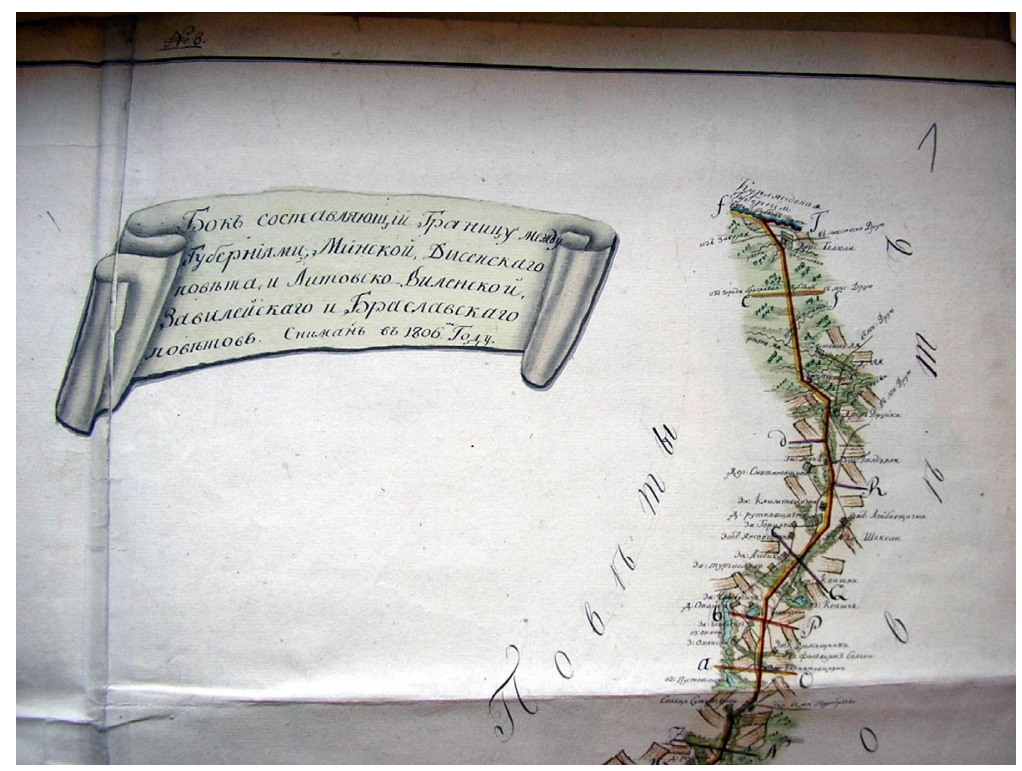

10 pav. Ribos tarp Vilniaus ir Minsko gubernijų planas; lapo Nr. 8 fragmentas

1807 m. „Rusijos imperijos gubernijų ir sričių atlase“, žemėlapyje Nr. 7, pavaizduotos Kuršo, Minsko, Smolensko, Lietuvos Vilniaus ir Lietuvos Gardino bei Baltarusijos Vitebsko ir Baltarusijos Mogiliovo gubernijos (11 pav.). Atlaso žemėlapiai be simbolikos. Žemėlapyje pažymèta Lietuvos Vilniaus ir Lietuvos Gardino gubernijų rytinė, pietinė bei vakarinė ribos apytikriai sutampa su atitinkamomis Pavelo I nustatytomis Lietuvos gubernijos ribomis. $1810 \mathrm{~m}$. spalio 6 d. caras Aleksandras I patvirtino „Lietuvos Vilniaus gubernijos padalijimo (razmeževaniji) instrukciją“ (12 pav.), kurioje dar prisimenama valakų reforma ir Lietuvos Statutas. Žemėlapių depas $1812 \mathrm{~m}$. reorganizuotas i Karo topografijos depą prie Generalinio kariuomenès štabo. 

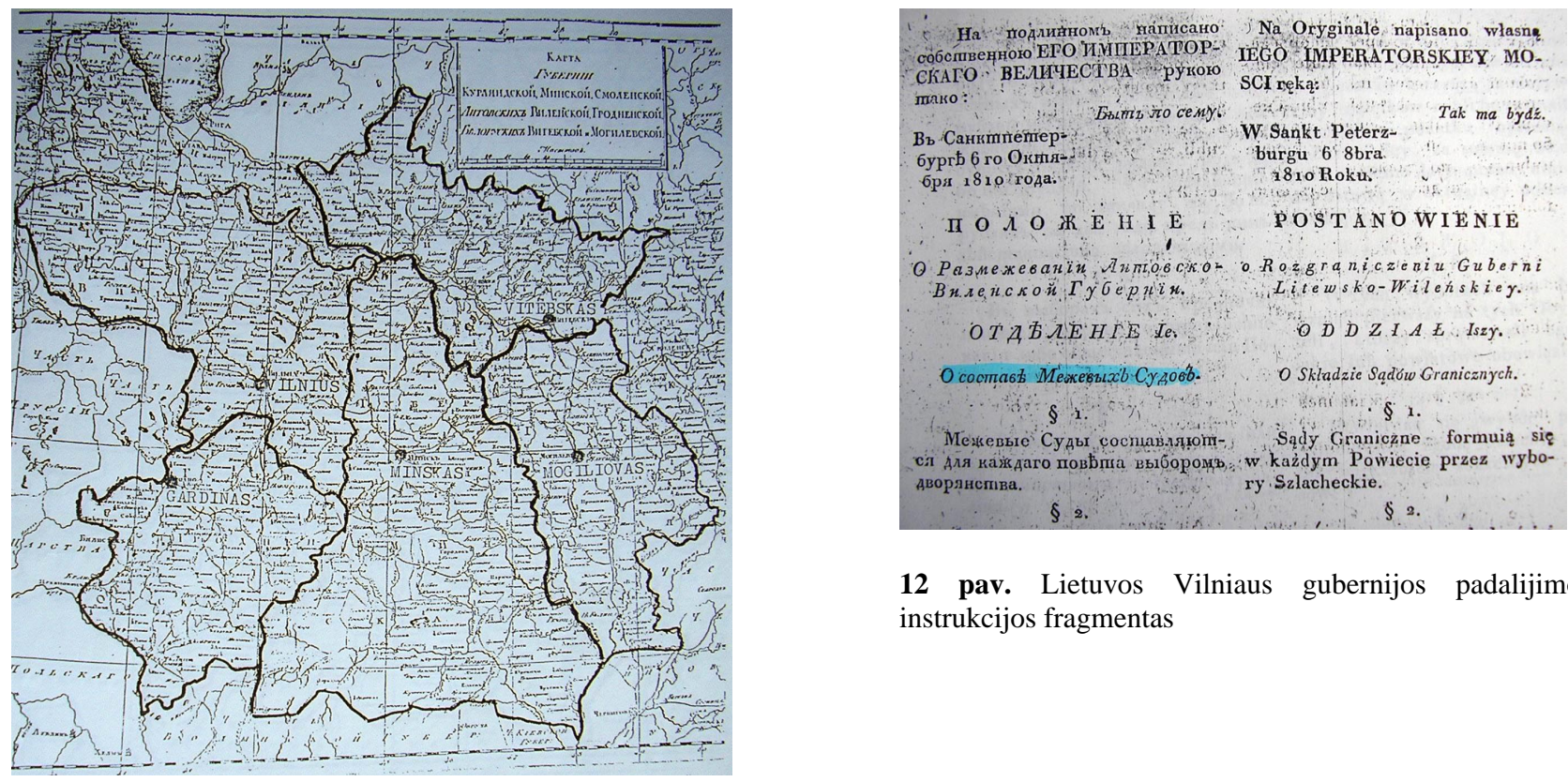

12 pav. Lietuvos Vilniaus gubernijos padalijimo instrukcijos fragmentas

11 pav. Kai kurios Rusijos gubernijos

Prancūzų revoliucijos veikiamas caras Aleksandras I stengèsi palaikyti liberalesnes idejjas ir Rusijoje. Tuo pasinaudojo Lietuvos bajorai. Jų igaliotas Mykolas Kleopas Oginskis $1811 \mathrm{~m}$. kreipėsi i carą, prašydamas atkurti autonomijos teisėmis Lietuvos Didžiają Kunigaikštystę teritorijoje (apie 485 tūkst. kv. km.), buvusioje dar iki Liublino unijos, kurioje nuo 1529 m. iki prašymo įteikimo galiojo Lietuvos Statutas. Caras iki karo su Napoleonu atsakymo nebuvo davęs.

Caras Aleksandras I i Vilnių buvo atvažiavęs dar kartą $1812 \mathrm{~m}$. ir puotos Vingio parke metu sužinojo, kad Napoleono kariuomenè persikèlè per Nemuną ir žygiuoja ị Vilnių. Tuo metu Vilniuje buvo apie 7000 rusų kareivių, kurie kartu su caru pasitraukè i Rusijos imperijos gilumą. Prancūzijos kariuomenė užèmé Lietuvą. Lietuva stengèsi pasinaudoti šiuo momentu ir atkurti valstybingumą. Napoleonas buvo sutiktas pagarbiai ir palankiai, prašyta atkurti LDK, bet gautas neaiškus atsakymas. Buvo sudaryta tik laikinoji Lietuvos valdžia Lietuvos Vilniaus, Lietuvos Gardino ir Minsko gubernijose (apie 138 tūkst. kv. km.), kuriai vadovavo Stanislovas Saltanas, sajungos su Lenkija šalininkas. Napoleonui rūpejo ne Lietuvos valstybingumo atkūrimas, o kaip gauti daugiau maisto kariuomenei išmaitinti ir Lietuvos vyrų kariuomenei papildyti, ir tai jam pavyko. Jo kariuomenejje prieš rusus kariavo Lietuvos ir Lenkijos kariniai daliniai. Tai buvo savotiška koalicija su Prancūzija, kuri Lenkijai, nors ir pralaimèjus Napoleonui, buvo naudinga, deja, Lietuvai - pragaištinga. Napoleonas 1812 m. ikūrẻ Varšuvos kunigaikštystę, kuriai priskyrė per trečiaji Lietuvos padalijimą Prūsijai tekusią Užnemunę bei Suvalkų kraštą, nes juos caras Pavelas I žemėlapiuose jau buvo ivvardijęs kaip Lenkijos Karalystės dalis. Vèliau, XX a. pradžioje atkuriant valstybingumą etnografinėje teritorijoje, šis Napoleono sprendimas komplikavo Lietuvos ir Lenkijos santykius.

Kovai prieš Prancūziją susivienijo keturios didžiosios valstybės - Austrija-Vengrija, Prūsija, Rusija ir D. Britanija, kurios, nugalejjusios Prancūziją, $1815 \mathrm{~m}$. birželio $9 \mathrm{~d}$. Vienoje baigè braižyti naują Europos žemėlapi. Vietoje Napoleono ikurtos Varšuvos Kunigaikštystès buvo atkurta Lenkijos Karalystè. Deja, keičiant valstybių sienas tautu nuomonès nebuvo paisoma, taigi ir Lietuvos Didžioji Kunigaikštystė nebeprisiminta. Caras Aleksandras I $1815 \mathrm{~m}$. Lenkijos Karalystę prisijungė prie Rusijos, leido jai turèti nedidelę kariuomenę, seimą ir tvarkytis vadovaujantis Napoleono kodeksu. Paryžiuje 1815 m. rugsėjo 26 d., carui Aleksandrui I pasiūlius, ikurta Šventoji sajunga, kuri turèjo užtikrinti ramybę Europoje.

Vienos konferencijos sprendimai pažymèti $1818 \mathrm{~m}$. Rusijos imperijos atlase [14]. Tai tas pats $1807 \mathrm{~m}$. atlasas, papildytas Lenkijos Karalystės ir Didžiosios Suomijos Kunigaikštystės žemėlapiais. Prie Lenkijos karalystės Augustavo vaivadijos priskirta Užnemunè ir Suvalkų kraštas, o kita LDK dalis žymima kaip Rusijos gubernijos. Deja, Vienos konferencijoje Europos didžiosios valstybès (imperijos) patikèjo melu, kad LDK yra slaviškos tik aplenkintos žemės, nes per jas rusai plūdo ị Vakarų Europą. Tai buvo didžiulis smūgis Lietuvos valstybingumo atkūrimui.

Praslinkus karui, Rusija, nugalejusi prancūzus, Lietuvoje pradèjo dar labiau stiprinti savo valdžią. Vienas iš tokių žingsnių buvo 1820 m. issteigta Vilniaus rūmų turtų valdytojo kanceliarija (uždaryta 1917 m.). Karo topografijos depas dar labiau plètė savo veiklą, todèl $1822 \mathrm{~m}$. reorganizuotas ị Karo topografų korpusą, kuris intensyviai dirbo imperijos pakraščiuose. Vienas iš pirmujų Karo topografų korpuso darbų buvo $1822 \mathrm{~m}$. nustatyta muitų siena su Lenkijos Karalyste, Lietuvoje sutapusi su Nemuno kairiuoju krantu. 


\section{Caro Nikolajaus I laikų žemèlapiai ir dokumentai}

Caras Nikolajus I valdè nuo 1825 iki 1855 metų. Jis 1829 m. patvirtino Žemètvarkos ịstatymą ir pertvarkè žemėtvarkos valdymą. Justicijos ministerijos žinioje ikurtas Matininkų korpusas, kuriam buvo pavaldžios gubernijų žemètvarkos kanceliarijos. Carui issakius, $1829 \mathrm{~m}$. Sankt Peterburge sudarytas Rusijos imperijos gubernijų, sričių, Lenkijos Karalystės bei Suomijos Kunigaikštystės atlasas [15]. Jame yra Vilniaus ir Gardino guberniju generaliniai žemèlapiai (13 pav.). Juose pažymėta rytiné, pietinè ir vakarinè šių gubernijų riba apytikriai sutampa su ankstesnių carų nustatytaja. Žemėlapyje pažymèta, kad nuo Palangos iki Smalininkų eina siena su Prūsijos Karalyste; nuo Smalininkų iki Gardino riba eina Nemunu, toliau - Bobro, Narevo, Bugo upėmis iki Orchovkos kaimelio ir ribojasi su Lenkijos Karalyste. Šiame atlase gubernijų herbai nebraižyti. Prie Vilniaus ir Gardino gubernijų neberašoma, kad jos Lietuvos, o prie Vitebsko ir Mogiliovo guberniju nèra nuorodų, kad jos Baltarusijos. Atlasas papildytas ir pakartotinai išleistas 1835 metais.

Caras Nikolajus I $1843 \mathrm{~m}$. liepos $1 \mathrm{~d}$. Vilniaus gubernija padalijo i Vilniaus ir Kauno gubernijas. Vilniaus gubernijos ribos buvo praplèstos į rytus, prijungiant lietuviškus Dysnos ir Vileikos rajonus (arba apskritis), bei i pietus, prijungiant lietuvišką Lydos apskritị (14, 15 pav.).

1826 m. ikurtas „Jo imperatoriškosios didenybès asmeninès kanceliarijos III skyrius“ - slaptoji policija. Ji Lietuvoje atskleidè visas prieš caro valdžią nukreiptas slaptas organizacijas pačioje jų veiklos pradžioje. Žinoma ne be pačių lietuvių pagalbos...

Vykdant Vilniaus krašto nutautinimo politika, 1829 m. ikurta Vilniaus „četvertinkos“ dvarų valdyba (uždaryta 1912 m.). 1831 m. i̇vyko Lietuvos sukilimas prieš caro valdžią, kuris, deja, buvo nesékmingas. Sukilimą numalšinus prasidejjo Lietuvos žmoniu trėmimai ir represijos. Po sukilimo konfiskuoti dideli plotai lietuviškų žemių (2890 dvaru). Jose pradèta planingai ikkurdinti rusų kolonistus. 1832 m. gegužès 13 d. caro Nikolajaus I ̨̇sakymu uždaromas Vilniaus universitetas, o rūpintis Lietuvos švietimo reikalais pavesta Minsko gubernijai. Vilniaus vyskupijoje (popiežiaus Pijaus VIII pontifikato metu) uždarytos 29 bažnyčios ir 49 vienuolynai, o ju žemès nusavintos. $1837 \mathrm{~m}$. Augustavo vaivadija tapo Augustavo gubernija.

Kariškiai buvo priversti daugiau rūpintis imperijos apsauga ir nebespejjo vykdyti civilinėms reikmėms reikalingu darbų, todèl prie Valstybès turtų ministerijos $1838 \mathrm{~m}$. isteigtas Civilių topografų korpusas. Civilių topografų korpuso nuostatus patvirtino pats caras $1838 \mathrm{~m}$. kovo 7 d. (16 pav.). $1840 \mathrm{~m}$. liepos 7 d. panaikinamas Lietuvos statuto galiojimas ir i̇vedami Lietuvoje Rusijos isstatymai. $1841 \mathrm{~m}$. suaktyvejo kitų Lietuvos bažnytinių žemių nusavinimas. 1843 m. ịsteigta Vilniaus gubernijos turtu valdyba (uždaryta 186206 06). 1843 m. gegužès 17 d. Vilniuje buvo įsteigta Vilniaus Gardino, Minsko ir Kauno gubernijų centrinè dvarininkiškos kilmės reikalų revizijos komisija. Šiai komisijai šlèkta privalëjo pristatyti savo dvarininkiškos kilmės įrodymus. Daugelis neturejjo jokių dokumentų, kiti, nors ir turejjo, negalèjo apsimokèti neišvengiamu išlaidu, susijusių su „dvarininkišku““ teisių paieškomis, todèl jų žemès ir turtas buvo nusavinti. $1844 \mathrm{~m}$. balandžio $15 \mathrm{~d}$. ikurtas Vilniaus gubernijos dvarininkų valdų inventoriu patikrinimo ir sudarymo komitetas (uždarytas 185804 19).

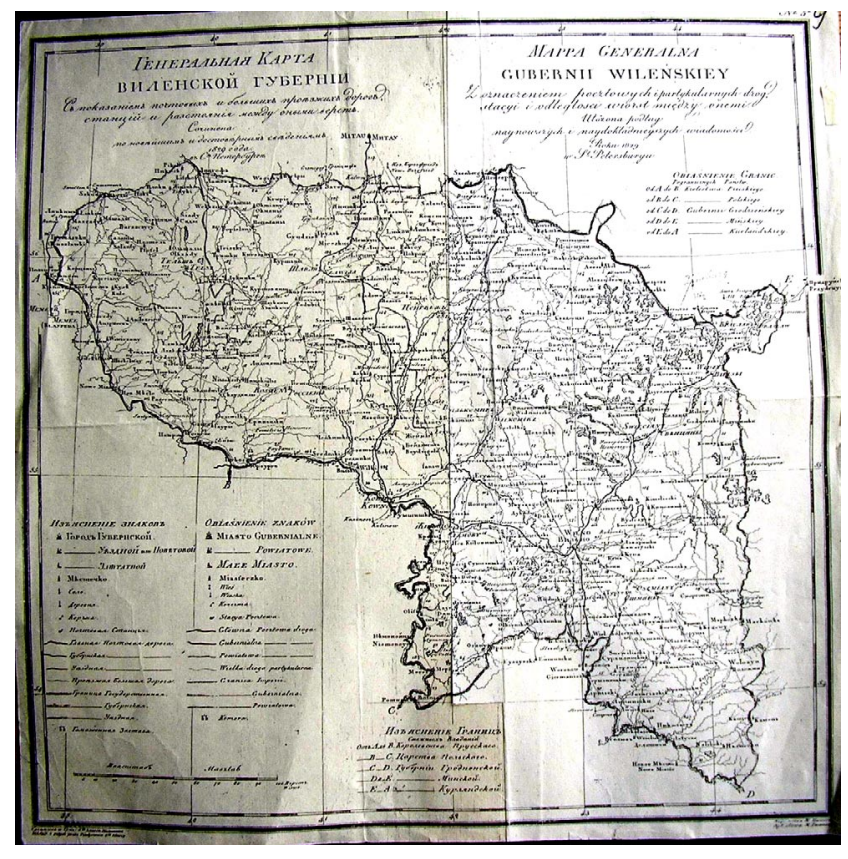

13 pav. Vilniaus gubernijos generalinis žemèlapis

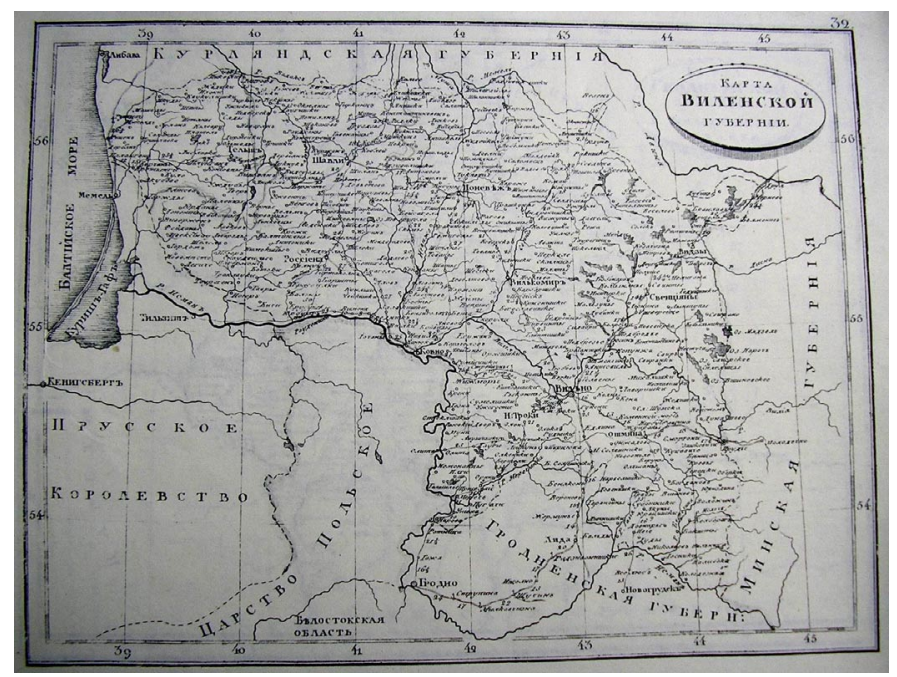

14 pav. Vilniaus gubernijos žemèlapis po Vilniaus ir Kauno gubernijų padalijimo 


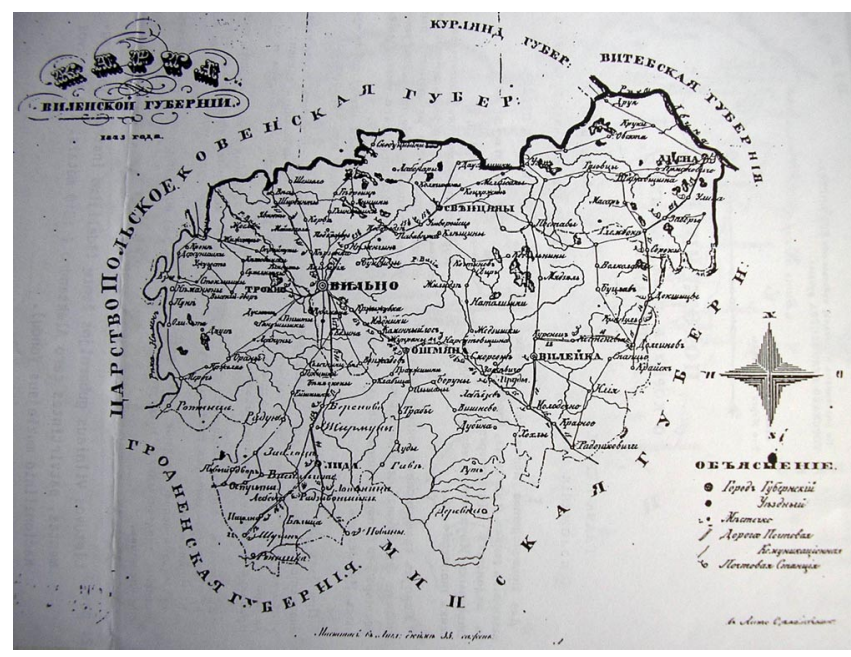

15 pav. Kauno gubernijos žemèlapis

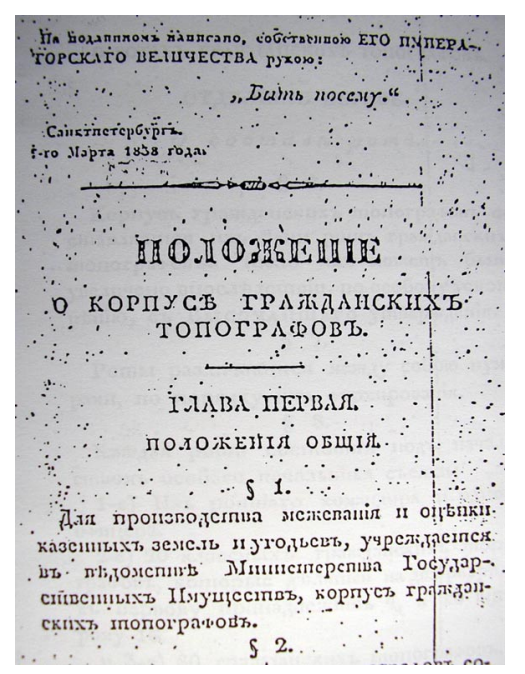

16 pav. Civilių topografų korpuso nuostatų fragmentas

Vidaus reikalų ministerijoje $1845 \mathrm{~m}$. issteigta Rusijos geografų draugija. Pramanytas naujas rusifikacijai parankus viso istorinio ir politinio regiono pavadinimas - Vakarų kraštas, arba tieisog Vakarų Rusija. Atsirado ir šio termino vedinių regiono dalims pavadinti. Buvusioms LDK žemėms, XVIII a. pabaigoje tekusioms Rusijai, ilgainiui prigijo Šiaurès vakarų krašto pavadinimas. Rusifikacinès geografijos terminijos įvedimas buvo viena iš tos specifinès, tik šiam regionui taikomos, rusinimo politikos sudedamujų dalių. Ši politika buvo grindžiama XIX a. ketvirtajame dešimtmetyje pradèta plètoti politizuota istoriografine koncepcija, esą LDK susikūrè ir plètojosi rusų civilizacijoje iš esmès kaip viena iš rusų valstybių ir buvo net Maskvos konkurentė kovoje dèl rusų žemių suvienijimo. Vienas iš tokio teiginio argumentų - tai susigiminiavusios kai kurių Rusijos carų ir LDK kunigaikščių šeimos. 1850 m. Matininkų korpusas sukarintas. Jis pradejo veikti karinio dalinio principu.

Siekdamas sureguliuoti santykius su katalikų bažnyčia popiežiaus Pijaus IX pontifikato metu caras Nikolajus I 1847 m. pasirašė konkordatą su Šv. Sostu. Kiek vėliau, 1849 m., pertvarkyta bažnytinė provincija. Nuo Vilniaus vyskupijos buvo atskirti Kauno, Panevėžio, Ukmergès, Utenos, Obelių, Zarasų, Kuršo ir Žemgalos dekanatai ir prijungti prie Žemaičių vyskupijos. Žemaičių, vyskupystė 1849 m. pradèta vadinti Telšiais.

1849 metais išleistas dar vienas Rusijos imperijos atlasas [16].

\section{Caro Aleksandro II laikų žemėlapiai ir dokumentai}

Caras Aleksandras II valdè nuo 1855 iki 1881 metų. Tuo laikotarpiu Vilniaus ir Gardino gubernijų, o kartu ir su jomis tapatinama Lietuvos etnografinių žemių, rytine riba išliko apytikriai tokia pati, kaip valdant carui Nikolajui I. Tai pažymėta 1860 m. smulkiame Rusijos imperijos atlase. Jame yra žemėlapis Nr. 6, kuriame vaizduojamos Lifliandijos, Estijos, Kuršo, Kauno, Vilniaus, Gardino ir Minsko gubernijos. Žemėlapyje pateikti gubernijų herbai: Vilniaus - Vytis, o Minsko - dvigalvis Rusijos erelis ir t. t. 1864 m. išleistas Vakarų Rusijos krašto ir Lenkijos Karalystès atlasas. Jame jau be herbų pavaizduotos į Vilniaus, Kijevo ir Varšuvos karines apygardas įeinančios gubernijos [17]. Matyt, siekiant ištaisyti 1815 m. Vienos kongreso klaidą, Užnemunę ir Suvalkų kraštą atskirti nuo Lenkijos Karalystès, 1867 m. sausio 13 d. iš šiaurinès Augustavo gubernijos dalies sudaryta Suvalkų gubernija. Ji pažymèta $1871 \mathrm{~m}$. Rusijos imperijos detaliame atlase [18]. Liko pavaldi Varšuvos generalgubernatoriui. Šio atlaso žemėlapiuose gubernijų herbai nebraižyti (17 pav.). 1867 m. Matininkų korpusas pradèjo veikti kaip civilinė organizacija.

Caro valdžia, tikriausiai nujausdama galimų neramumų pradžią, susidomėjo tautine imperijos pakraščių sudètimi. 1857 m. statistinius duomenis per kunigus surinko rusų akademikas Koppen. $1861 \mathrm{~m}$. Lebedkin išleido brošiūrą „O plemenom sostave narodonaselenija zapadnovo kraja Rosijskoj imperiji“. Matyt, ivertinęs statistinius duomenis, $1862 \mathrm{~m}$. caras Aleksandras II išleido issakymą steigti Lietuvoje tik rusiškas pradžios mokyklas. $1860 \mathrm{~m}$. liepos $2 \mathrm{~d}$. isteigta Vilniaus gubernijos žemės ribų matavimo komisija (uždaryta 1863 m.), o 18630301 išleistas caro įsakas dẻl privalomo žemės išpirkimo įvedimo Kauno, Vilniaus, Gardino, Minsko gubernijose ir dalyje Vitebsko gubernijų. 1863 m. Lietuvoje ivyko sukilimas prieš caro valdžią, kuris ir vėl buvo nesėkmingas. Po jo konfiskuota apie 60000 dešimtinių žemès, i Rusijos gilumą ar Sibirą išgabenta ištisi kaimai, o vietoje ištremtujų ikurdinti rusai. Štai ką apie tai rašè net pačių rusų istorikas A. H. Kirkoras: „1863 metai kaip žiaurus uraganas praūže per visq kraštq ir nusinešẻ tūkstančius auku. Tūkstančiai nukautu mūšiuose, daugybe sušaudytu ir pakartu be teismo nuosprendžiu, tūkstančiai išsiustu $\dot{k}$ katorga ir Sibira, sudeginti ir ištuštèje kaimai, ištisu gyvenviečiu iškeldinimas, dvarininku luomo sunaikinimas. Teisès isigyti dvara ir valstybinę tarnyba netekimas, apribojimas mokymosi aukštosiose mokyklose, geranorišku reformu, pavyzdžiui, zemstvu, viešo teismo ir kt., kuriomis naudojosi centrinès gubernijos, pristabdymas štai kokie užsidegimo ir lengvabūdiško tikëjimo begèdišku užsienio kurstymu padariniai.“ [19]. Caras 1864 m. gegužès 22 d. patvirtino Šiaurès vakarų krašto surusinimo programą. I Rusijos didvyrių rangą su „rusų pradų“ atkuriamaja 


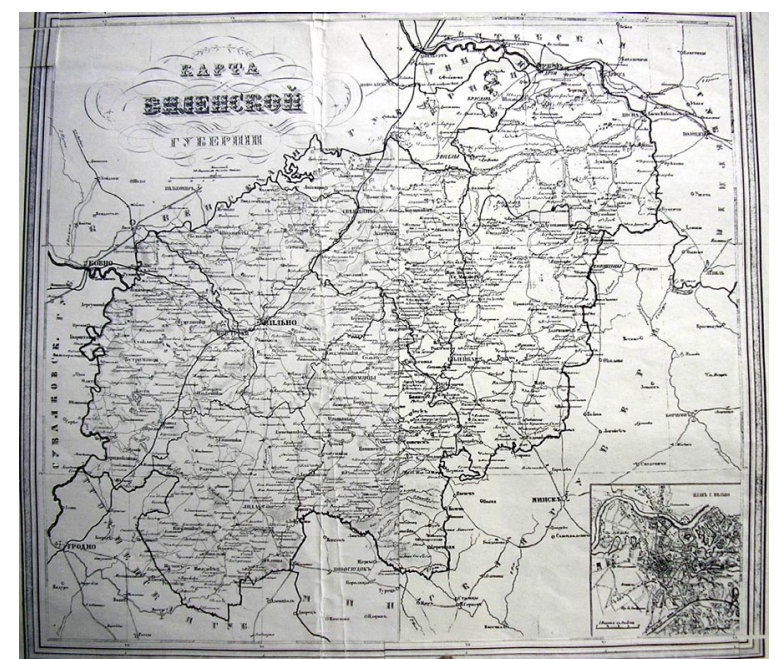

17 pav. $1871 \mathrm{~m}$. Vilniaus gubernijos žemėlapis programa 1863 m. sukilimas iškèle ir M. Muravjovą, žmonių pramintą koriku. „M. Muravjovo epochoje“ politizuoti, rusifikacijai parankūs geografiniai pavadinimai (Vakarų kraštas, Vakarų Rusija, Šiaurès vakaru kraštas) plačiai ir tvirtai isigalejo oficialioje raštvedyboje ir rusų spaudoje. Taip pat buvo keičiami i rusiškus ir lietuviški vietovardžiai. Mažeikiai pavadinti Muravjovo vardu, miestų gatvių pavadinimai vien rusiški ir t. t. Tokiai veiklai plètoti 1867 m. issteigtas Rusijos geografų draugijos Siaurès vakarų skyrius, kurio centras buvo Vilniuje.

Po 1863 m. sukilimo dvarininkams katalikams Muravjovas ivedé papildomą $10 \%$ mokesti. Aleksandras II už vyskupo M. Valančiaus nepaklusnumą Rusijos okupacinei valdžiai ir $1863 \mathrm{~m}$. sukilèlių rèmimą $1864 \mathrm{~m}$. Telšių (žemaičiu) vyskupijos centrą perkèlè ị Kauną.

$1864 \mathrm{~m}$. caro valdžios nurodymu vèl atliktas gyventojų surašymas. Duomenys paskelbti „Statistinejje Vakarų Rusijos krašto lentelëje“, kurią, Vidaus reikalų ministerijos pavedimu, sudarè Batiuškov, aktyvus „,rusų pradų atkūrimo“ politikos veikejjas [20]. Jis buvo ir Vilniaus gubernijos švietimo globejjas. Matyt, statistiniai duomenys nepatenkino caro valdininkų, todėl 18650913 vidaus reikalų ministro P. A. Valujev slaptu isakymu Nr. 141 uždrausta lietuviška spauda. $1865 \mathrm{~m}$. išleistos specialios instrukcijos, kaip rusams Lietuvoje isigyti dvarus ir namus. 1866 m. Rusijoje issteigta Lietuvos dvarų supirkinèjimo bendrovè. 18670516 išleistas istatymas dèl valstybinių valstiečiu žemės išpirkimo Vilniaus, Kauno, Gardino, Minsko, Vitebsko gubernijose. Karinès prievolès istatymas išleistas 18740101 ir įvesta visuotinè karo prievolè. 1874 m. įsteigta Vilniaus gubernijos cerkvių statybos komisija, kuri užsiiminèjo ir katalikų bažnyčiu pertvarkymu i cerkves [20]. 18820603 paskelbtas istatymas dèl „laisvuju žmoniǔ“ žemès išpirkimo, 18860609 - dèl amžinujų činčininkų žemès išpirkimo. Šie îstatymai galutinai nuskurdino mažažemius kaimo žmones. Jie nepajėgè išpirkti naudotos žemės ir buvo priversti palikti savo gimtąsias vietas. Jose vèliau issikurdavo kolonistai. 1868 m. prasidejjo masinè žmonių emigracija iš Lietuvos i Vakarų Europos ir Amerikos šalis.

\section{Carų Aleksandro III ir Nikolajaus II laikų žemèlapiai ir dokumentai}

Caras Aleksandras III valdė nuo 1881 iki 1894 metų. Jo valdžios metais Vakarų Rusijos kraštui priskirtų Vilniaus, Kauno, Suvalkų ir Gardino gubernijų ribos išliko iš esmès nepakitę, t. y. apytikriai tokios pat kaip valdant carui Aleksandrui II. Tai pažymėta 1882 m. lietuviškų Vilniaus, Kauno ir Gardino gubernijų žemėlapyje, kuris yra Lietuvai skirto 1882 metų namų kalendoriaus priedas (18 pav.). Žemèlapis $1881 \mathrm{~m}$. spalio 21 dieną patikrintas Vilniaus gubernijos cenzūros.

Lietuvos turtų nusavinimui įteisinti $1882 \mathrm{~m}$. gruodžio 21 d. įsteigta Vilniaus ir Kauno gubernijų žemdirbystės ir valstybès turtų valdyba, kuri valdè ir tvarkè miškus, žemę, vandenis (panaikinta 19180403 ) [12].

Carinès Rusijos Lietuvos nutautinimo politikos naikinant katalikų bažnyčias pavyzdys - Kražių skerdynės. 1893 m. buvo issakyta Kražių bažnyčią atiduoti rusams. Vietos gyventojai atkakliai priešinosi atsiųstiems kazokams, išprovokavusiems didžiules skerdynes, kurių ir po šiai dienai žmonès dar negali užmiršti.

Caras Nikolajus II valdė nuo 1894 m. iki 1917 metų. Iki pirmojo pasaulinio karo Vilniaus, Kauno, Suvalkų ir Gardino gubernijų ribos išliko iš esmès nepakitę (19 pav.).

Tęsiant ankstesnių carų politiką, vykdomo nutautinimo rezultatais įsitikinti $1897 \mathrm{~m}$. atliktas Rusijos imperijos gyventojų surašymas. Jo duomenys paskelbti Vidaus reikalų ministerijos statistikos komisijos leidinyje, kurị redagavo Troinovskis. Caro administracija 1897 m. visuotinio Rusijos imperijos gyventojų surašymo metu žemaičius atskyrè nuo lietuvių ir duomenis apie vienus ir kitus rašè skirtingose skiltyse.

Petrodvorece (Sankt Peterburgo priemiestis) $1897 \mathrm{~m}$. vasarą ivyko caro Nikolajaus II susitikimas su Vokietijos kaizeriu Wilhelmu II. Caras prašė kaizerio uždrausti lietuviškų knygų spausdinimą Mažojoje Lietuvoje.

Vilniaus krašto gyventojai caro valdininkų represijoms priešinosi kaip įmanydami, todèl $1901 \mathrm{~m}$. įsteigtas Vilniaus gubernijos kalejjimų statybos komitetas (panaikintas 1906 m.). Vis tik pamažu ryškejjo pasipriešinimo rezultatai. 19011218 Šv. Mikalojaus bažnyčia Vilniuje buvo atiduota lietuviams. 19030608 isteigta Vilniaus gubernijos Žemès reikalų komisija, kuri kontroliavo šiek tiek pažangesnès - Stolypino agrarinès reformos eigą (likviduota 1918). 1904 m. balandžio 4 d. caras panaikino lietuviškos spaudos draudimą. 19050514 panaikintas draudimas lietuviams pirkti žemę Lietuvoje. Vilniuje, $1905 \mathrm{~m}$. lapkričio 21-22 dienomis dirbo Didysis Vilniaus Seimas. Jo darbe dalyvavo per 1000 atstovų iš visos Lietuvos. Mažajai Lietuvai atstovavo Jonas Vanagaitis. Lietuvai buvo reikalaujama didelès autonomijos Rusijos imperijoje. Didysis Vilniaus Seimas prièmė tokio turinio nutarimą: 


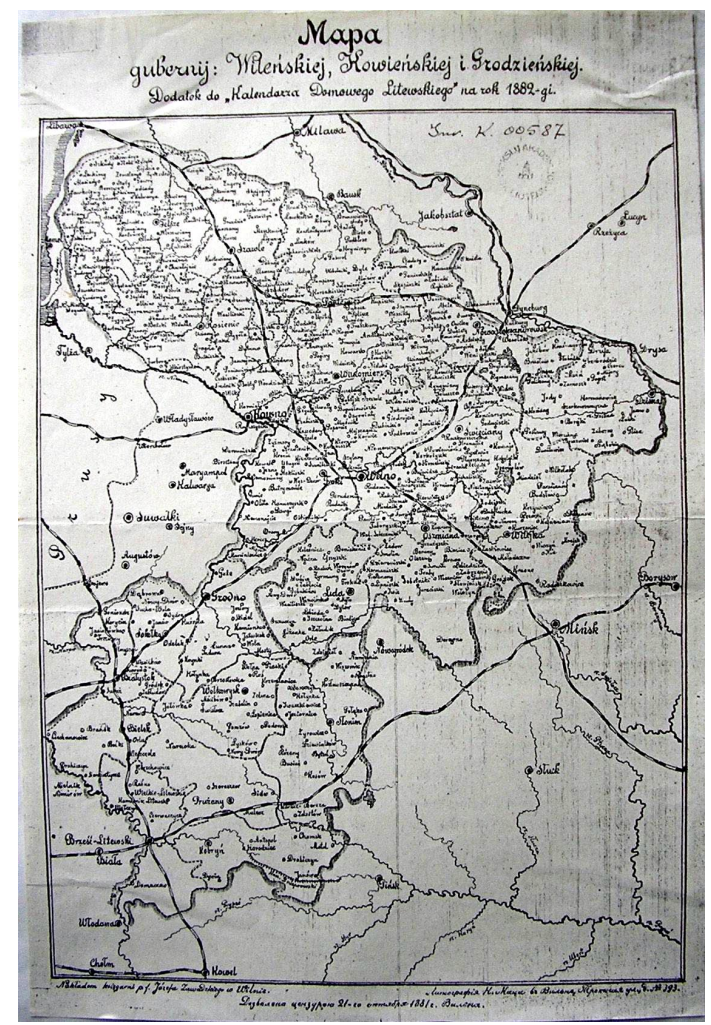

18 pav. 1882 m. Vilniaus gubernijos žemėlapis

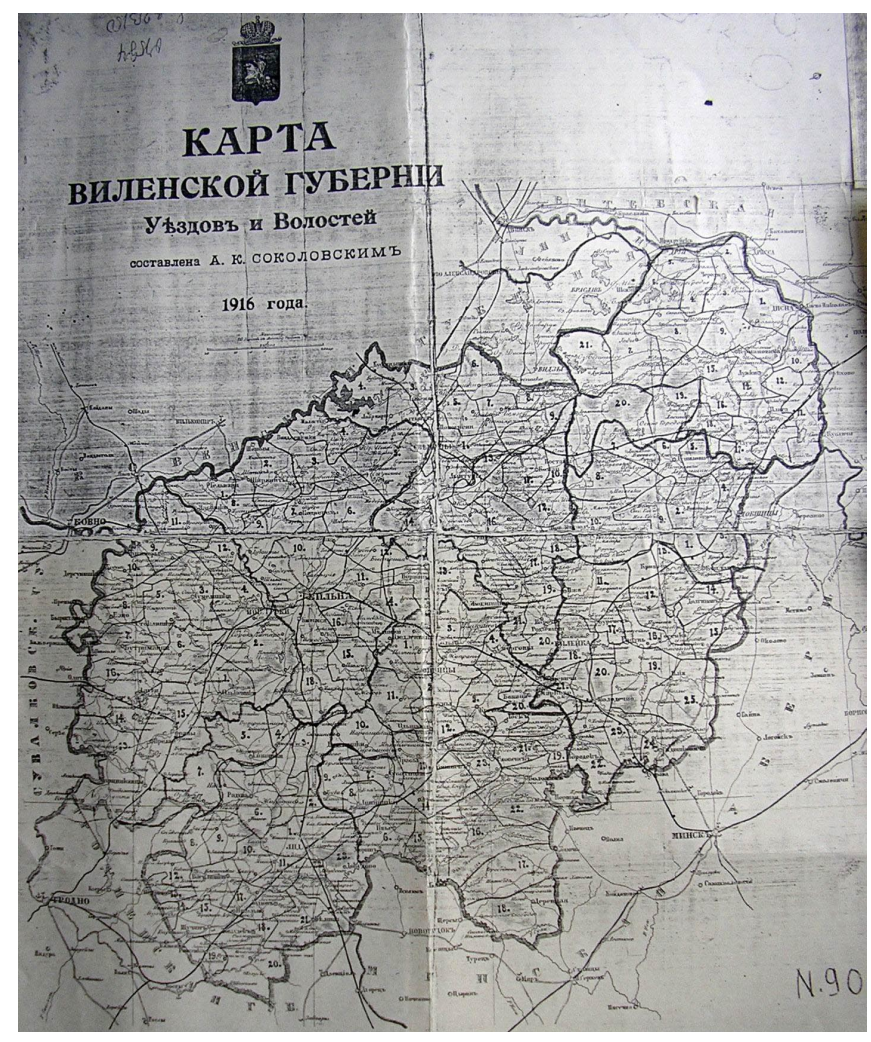

19 pav. 1916 m. Vilniaus gubernijos žemèlapis

I. Dabartinis padejimas Rusijoje ir Lietuvoje.

Pripažindami, jog dabartine caro vyriausybè yra pikčiausiu mūsu priešu, jog dabar prieš ta vyriausybę pasikèlè visi Rusu valstijos kraštai, jog geresni gyvenima galima isigyti, tik laimejjus kova su senaja tvarka, susirinkime dalyvavusieji lietuviai nutaré:

Šviestis, rištis ir stoti kovon drauge su sukilusia visu Rusijos tautu liaudimi.

II. Lietuviu autonomija.

Kadangi Lietuvos gyventoju reikalai pilnai gali būti užganèdinti tiktai prie tikros mūsu krašto autonomijos (savivaldos) ir kadangi norima, idant kitos Lietuvoje begyvenančios tautos galètu pilna laisve naudotis, Lietuviu suvažiavimas nusprende:

Reikalauti Lietuvai autonomijos su Seimu Vilniuje, išrinktu visuotinu, lygiu, tiesiu ir slaptu balsavimu, neskiriant lyties, tautos ir tikejimo.

Toji autonomiškoji Lietuva turi būti sudèta ǐ̌ dabartinès etnografiškosios Lietuvos, kaipo branduolio, ir tu pakraščiu, kurie dèlei ekonomišku, kultūrišku, tautišku arba kitu priežasčiu traukia prie to branduolio ir kuriu gyventojai priklausyti prie jo panorès.

Kadangi susirinkę Vilniuje ant Lietuviu suvažiavimo Suvalku gubernijos lietuviai vienbalsiai pripažino reikalingu drauge su kitu guberniju lietuviais kovoti už autonomiškaja Lietuva, tai suvažiavimas nutarè, kad Suvalku gubernijos lietuviai turi büti priskirti prie autonomiškosios Lietuvos.

Santykiai su kaimyniškomis Rusijos šalimis turi būti paremti ant federacijos pamatu.

III. Kokiu būdu iškovoti autonomija.

Kad igyti autonomija, pirmučiausiai reikalinga yra galutinai sugriauti dabartine prispaudimo tvarka. Tam tikslui reikia vienyti visas Lietuvos politiškuju partiju ir pavieniu ypatu pajègas. Susivienijus namieje, pridera mums jungtis su visomis kitomis Rusijos tautomis, kurios padeda griauti ta tvarka, o kol kas reikia: nemokèti jokiu mokesčiu, uždarinèti monopolius, neleisti vaiku i rusiškas pradedamasias mokyklas, neiti Kauno, Vilniaus ir Gardino gubernijose i valstiečiu teismus ir visas kitas dabartinès valdžios istaigas, neleisti savo broliu $\dot{k}$ kariuomenę, reikalui prasidejus, streikuoti visiems darbo žmonèms miestuose ir sodžiuose.

IV. Valsčiai, mokyklos ir bažnyčios.

Visuose Lietuvos valsčiuose turi būti vartojama prigimta žmoniu kalba, visus reikalus vedant.

Kadangi dabartine mokykla yra tik ištautinimo ir ištvirkimo ¿̇rankiu, tai reikia visas tokias mokyklas paversti grynai tautiškomis, kur mokslas būtu išguldomas prigimta kalba, ir kad patys to krašto žmonès rinktu sau mokytojus. 
Kadangi Vilniaus vyskupystëje lietuviu bažnyčiose yra vartojama pamaldose lenkiška kalba su politišku tikslu, tai Lietuviu susirinkimas nutare vienbalsiai išreikšti Vilniaus vyskupystëje gyvenantiems ir kovojantiems lietuviams geriausì linkèjimq pasisekimo kovoje su lenkomanu kunigija už teises lietuviškos kalbos Lietuvos bažnyčiose ir papeikti šiandieninès bažnyčios tvarka Vilniaus vyskupystëje“ [21].

Jau 1905 m. lapkriti Rusijoje vykusios revoliucijos sąlygomis grupé lietuvių veikèjų su Jonu Basanavičiumi priešakyje iteikė vidaus reikalų ministrui grafui S. Vitei memorandumą, kuriame pabrěžè, kad lietuviu gyvenamają teritoriją sudaro Vilniaus, Kauno, Gardino, Suvalkų gubernijos ir dalis Kuršo. Rusijos valstybès I dūma posèdžiavo nuo 1906 m. gegužès 10 iki liepos 12 d. Jos darbe dalyvavę lietuviai deputatai reikalavo, kad vykdant žemės reformą Lietuva būtu išskirta iš rusiškų gubernijų kaip kraštas, turintis privačios žemės nuosavybès valdymo tradicijas. Rusijos valstybès II dūma posèdžiavo nuo $1907 \mathrm{~m}$. kovo 5 iki birželio 15 d. Diskusijose dalyvavę lietuviai deputatai, siekdami pabrěžti Lietuvos ir Rusijos tradicijų skirtumus, akcentavo, kad Lietuvoje žemę reikia atiduoti nuosavybẻn. Rusijos valstybès III dūma posèdžiavo nuo $1907 \mathrm{~m}$. lapkričio 14 d. iki $1912 \mathrm{~m}$. birželio 22 d. Joje dalyvavę lietuviai deputatai reikalavo žemès reformos vykdymą Lietuvoje perduoti Lietuvos autonominiam Seimui. Taip buvo propaguojama Lietuvos autonomijos idejja, iškelta $1905 \mathrm{~m}$. Vilniaus Didžiajame Seime. Lietuvos autonomijos klausimas buvo keliamas ir IV Dūmoje, kuri pradèjo darbą $1912 \mathrm{~m}$. lapkričio $24 \mathrm{~d}$.

Vilniaus gubernijos žemètvarkos komisija ir apskričių žemètvarkos komisijos sudarytos $1906 \mathrm{~m}$. (likviduotos 1917 m.). 19070308 Vilniuje ikurta Sajunga lietuvių kalbos teisėms atgauti Vilniaus krašto bažnyčiose. Caro valdžios isakymu $1909 \mathrm{~m}$. atliktas dar vienas gyventojų surašymas.

Šio šimtmečio pradžioje politine konfrontacija Europoje sustiprèjo ir subrandino Pirmaji pasaulinị karą. Karą $1914 \mathrm{~m}$. liepos 19 d. pradèjo dvi imperijos - Rusija ir Vokietija, nors 1914 m. sausio 14-18 d. ir buvo pasirašiusiuos tarpusavio sutartí, kurioje buvo nustatyta siena tarp šių imperijų, kuri dar griežčiau atskyrè Mažają Lietuvą nuo Didžiosios Lietuvos. Užbėgant ivvykiams už akių galima teigti, kad tai buvo savotiškas Molotovo-Ribentropo pakto prototipas... $1915 \mathrm{~m}$. rugsèji Vokietijos kariuomenè Lietuvą okupavo.

Pirmasis pasaulinis karas Rusijoje subrandino keletą revoliucijų. Paskutiniają 1917 m. spalị ívykdè bolševikai, po jos Rusiją pradëjo valdyti jų vadas Vladimiras Uljanovas-Leninas.

\section{Literatūra}

12. Vyriausioji archyvų valdyba prie Lietuvos Respublikos Ministrų Tarybos, Lietuvos centrinio valstybinio istorijos archyvo fondų žinynas. Vilnius, 1990, p. 33-196.

13. Бокъ, составляющій Границу между Губерніями Минской Дисенского повіъта и Литовско-Виленской, Завилейского и Браславского повіътовъ. Сниманъ въ 1806 Году. Масштабъ въ Аглинскомъ дюйме 2 верста. Землемеръ Губернскій СекретаръСергей Кобелевъ.

14. Атласъ Россійской Имперіи по новейшему расделенію на губерніи и области, сочиненный 1807 года при Главном Училище Правленіи для употребления в Губернских Гимназиях, а 1818 года внов исправленый и пополненый картами Царства Польского и Великого Княжества Финляндского.

15. Атласъ Россійской Имперіи, содержащій въ себеъ 51 губернію, 4 области, Царство Польское и Княжество Финляндское.[....] Исданній съ одобренія Военнотопографического Депо Надворнымъ советником и Кав. А. Савинковымъ, С.-Петербургъ, 1829 года.

16. Атласъ Россійской Имперіи, приспособленный к географическим учебникам в гимназиях и уездных училищах. Исдал А. Ободовский. Санкт-Петербург, Типография военно-учебных заведений, 1849.

17. Атлас Западно-Русского края и Царства Польского (Виленского, Киевского и Варшавского военных округов). С планами губ. городов. Спб., Полторацкий, Ильин и Ко, 1864.

18. Подробный атлас Российской империи с планами главных городов. 70 карт. С.-Петербург. Издание картографического заведения А. Ильина, 1871.

19. Kirkoras, A. H. Lietuva nuo seniausių laikų iki 1882 metų. Vilnius, 1995. 85 p.

20. Атлас народонаселения Западно-Русского края по Канцелярии заведывающего устройством православных церквей в Западных губерниях. Изд. 2-е, испр. и доп. Спб., 1864.

21. Laikraštis Vilniaus žinios 1905 m. lapkričio 24 d. 